\title{
CITRA PEREMPUAN \\ DALAM KABA ANGGUN NAN TUNGGA \\ KARYA AMBAS MAHKOTA
}

\author{
Ninawati Syahrul \\ Badan Pengembangan dan Pembinaan Babasa
}

\begin{abstract}
Abstrak
Karya sastra daerah Minangkabau cukup dominan menghadirkan tokoh perempuan. Apabila dihubungkan dengan sistem kekerabatan yang dianut masyarakatnya, yakni matrilineal, sangat menarik untuk mengkaji eksistensi tokoh perempuan. Penelitian ini bertujuan mendeskripsikan citra perempuan Minangkabau sebagai pribadi dan mendeskripsikan citra perempuan Minangkabau sebagai anggota masyarakat dalam kaba Anggun Nan Tungga. Penelitian ini bersifat deskriptif. Untuk melihat gambaran citra perempuan dalam penelitian ini digunakan pendekatan objektif sastra yang dikaitkan dengan teori psikologi wanita, psikologi umum, dan filsafat manusia. Citra perempuan yang digambarkan dalam kaba Anggun Nan Tungga menunjukkan bahwa pada umumnya tokoh perempuan mempunyai kepribadian sangat baik karena ia memiliki kedua aspek citra perempuan, yaitu citra perempuan sebagai pribadi dan citra perempuan sebagai anggota masyarakat. Hal itu sudah mencerminkan tokoh perempuan yang diidealkan. Perempuan merupakan tiang kokoh dalam rumah tangga dan masyarakat. Ia berfungsi memberikan arahan dan pengaruh besar bagi generasi muda.
\end{abstract}

Kata kunci: kaba, perempuan, citra, karya sastra

\begin{abstract}
Minangkabau literature are quite dominant in presenting female characters. If it is connected with the kinship system which is adopted by the community, matrilineal, it will become very interesting to learn about female characters. This study aims to describe the image of minangkabau women as a person and as the members of the community in the story of Anggun Nan Tungga. This is a descriptive study. To see the image of women in this study is using objective approach of literature which is associated with the theory of women psychology, general psychology and human philosophy. The image of women portrayed in the story of Anggun Nan Tungga denote that female characters generally have very good personalities because they have two aspect of the image of women, as a person and as the members of society. It is already reflecting idealized female figures. Women are sturdy pole in the household and society. They serve to provide direction and a major influence for the younger generation.
\end{abstract}

Keywords: story/tale, woman, image, literature 


\section{Pendahuluan}

Citra perempuan Indonesia pada saat ini dapat digambarkan sebagai manusia yang harus hidup dalam situasi dilematis, misalnya perempuan Indonesia yang berkarier. Menurut Armini (1986:45), perempuan pekerja tercitra sebagai perempuan yang berada dalam situasi berwajah ganda. Di satu sisi perempuan pekerja ingin memupus anggapan bahwa tugas utama perempuan adalah di sektor domestik dan anggapan itu dikokohkan oleh masyarakat. Kemudian di satu sisi perempuan pekerja ingin mengubah pandangan kedudukan perempuan tidak setara dengan pria, tetapi di sisi lain perempuan justru bertindak sebaliknya.

Lebih lanjut diungkapkan perempuan Minangkabau tidak dapat disangkal lagi memiliki kedudukan yang sederajat dengan lelaki bahwa dalam kebudayaan Minangkabau perempuan justru mempunyai kedudukan yang jauh lebih tinggi dari pada kaum lelaki karena mereka dianggap penjaga dari harta pusaka keluarga (Soetrisno dalam Ridjal, 1993:108).

Masyarakat Minangkabau memiliki keunikan apabila dibanding dengan masyarakat kultur lainnya di Indonesia. Keunikan ini disebabkan oleh paham matrilineal yang dianut oleh masyarakat Minangkabau yang mengambil garis keturunan menurut garis ibu. Dengan paham yang dianutnya itu, peranan dan kedudukan perempuan menjadi lebih penting di dalam kehidupan masyarakat Minangkabau (Asri, 1996:3). Pentingnya posisi perempuan dalam keluarga juga diungkapkan oleh Holleman dan Vreede-De Stuers (dalam Baried, 1994: 6) yang mengatakan bahwa perempuan dalam sistem matrilineal, yaitu menurut garis keturunan ibu, kedudukan perempuan penting karena di tangannyalah tergantung kehidupan keturunan. Dalam sistem itu pihak perempuan adalah memegang keputusan dan berwenang menentukan kebijaksanaan. Untuk melihat bagaimana peranan dan kedudukan perempuan Minangkabau dalam kehidupan masyarakat dengan konsepsi budaya adatnya akan dilakukan penelitian melalui karya sastranya yaitu kaba.

Kaba, salah satu karya sastra tradisional Minangkabau, secara langsung atau tidak tentu akan memberikan gambaran tentang kultur Minangkabau termasuk perempuan dan segala aspek kehidupannya. Hal itu sesuai dengan pendapat Damono (1979:1), yaitu bahwa karya sastra diciptakan oleh sastrawan untuk dinikmati, dipahami, dan dimanfaatkan oleh masyarakat. Sejalan dengan itu, H.B. Jassin (1983:4) mengemukakan bahwa karya sastra selalu menarik perhatian karena mengungkapkan penghayatan manusia yang paling dalam, dalam perjalanan hidupnya di segala zaman dan di segala tempat di dunia. Melalui karya sastra sebagai basil kesenian, kita memasuki dunia pengalaman bangsa dan dalam sejarah dan masyarakatnya, menyelami apa yang pernah dipikirkan dan dirasakan dan dengan demikian menambah kearifan dan kebijaksanaan dalam kehidupan.

Menurut Soeratno (1994:14), sastra dipahami sebagai sarana "penghibur duka lara", sebagai pembawa rasa tenang, sebagai "pelipur hati bagi yang memendam cinta berahi", sebagai "perintang waktu", sebagai dokumen penyaji informasi masa lampau, sebagai legitimasi suatu kekuasaan, sebagai penyangga pranata sosial, sebagai pembawa ajaran moral, baik dalam kehidupan keluarga maupun dalam kehidupan masyarakat, dan sebagai pencerdas bangsa.

Kaba sama dengan 'kabar' (Junus, 1994a: 17; Navis, 1986: 243) sehingga juga berarti 'berita'. Sesuai dengan hakikatnya sebagai fiksi, cerita kaba mengungkapkan berbagai masalah kehidupan manusia dengan keunikan penyampaian yang spesifik. Penyampaian yang terjadi padu akan melukiskan kehidupan masyarakat Minangkabau yang kompleks dan dapat menyampaikan pesan sebaik-baiknya kepada masyarakat pembaca (Udin. 2006:99).

Sejalan dengan itu, Muhardi dan Hasanuddin W.S. (1992:20) menyatakan bahwa fiksi dibangun oleh dua unsur. Pertama, unsur intrinsik, yang meliputi (1) unsur utama yang berkaitan dengan alur atau plot, penokohan, dan latar atau setting dari ketiga unsur tersebut membentuk permasalahan yang intinya disebut tema dan amanat, dan (2) unsur penunjang yang berkaitan dengangaya bahasa. Kedua, unsur ekstrinsik, terbagi menjadi dua yaitu: (1) unsur utama yang berkaitan dengan imajinasi pengarang dan (2) unsur penunjang yang berkaitan dengan norma dan nilai sosial budaya.

Penokohan adalah pelukisan atau gambaran yang jelas tentang seseorang yang ditampilkan dalam sebuah cerita. Menurut Abrams (dalam Nurgiyantoro, 1995:165) penokohan adalah orang yang ditampilkan dalam suatu karya naratif atau drama. Kemudian mereka ditafsirkan pembaca memiliki kualitas moral dan kecendrungan tertentu seperti yang diekspresikan dalam ucapan dan apa yang dilakukan dalam tindakan. 
Berdasarkan pada hal tersebut, dirumuskan alasan pemilihan kaba Anggun Nan Tungga untuk dibicarakan dalam penelitian tersebut. Kaba tersebut merupakan kisah yang cukup populer dalam masyarakat Minangkabau. Kaba itu sudah ditranformasikan dan dipublikasikan dalam berbagai bentuk karya seni, seperti drama dan film.

Sosok perempuan yang ditampilkan di dalam kaba tentulah merupakan sosok citra yang ada di dalam gagasan dan ide pengarang. Tuntutan zaman yang berbeda karena perubahan dan perkembangan kemajuan teknologi pada manusia akan menyebabkan tuntutan yang berbeda pula pada kaum perempuan. Bertolak dari pemikiran tersebut, penelitian ini berusaha untuk mendeskripsikan citra perempuan dalam kaba Anggun Nan Tungga dan hubungannya dengan keadaan yang ada dalam masyarakat Minangkabau sesuai dengan sistem dan adat yang dianut. Dengan penelitian ini, diharapkan beberapa hal yang menyangkut pemikiran, sikap, pandangan, dan perilaku perempuan Minangkabau dapat dikenali dan diidentifikasikan. Pada tahap selanjutnya diharapkan akan dapat memberikan masukan positif dalam pengembangan kebudayaan nasional pada umumnya, pengembangan kesusasteraan daerah khususnya.

Sesuai dengan uraian pada bagian latar belakang, masalah yang akan diungkapkan dalam penulisan artikel adalah bagaimanakah citra perempuan dalam kaba Anggun Nan Tungga terutama sebagai pribadi dan sebagai anggota masyarakat dalam kehidupan Minangkabau?

Berdasarkan uraian yang telah dikemukakan tadi, tujuan penelitian adalah untuk mendeskripsikan citra perempuan Minangkabau sebagai pribadi dan sebagai anggota masyarakat dalam kaba Anggun Nan Tungga.

Penelitian artikel berikut dilakukan dengan analisis kualitatif dan metode deskriptif. Analisis kualitatif adalah analisis yang mengutamakan kedalaman penghayatan terhadap interaksi antar konsep yang sedang dikaji secara empiris (Semi, 1993:3). Metode yang digunakan adalah metode deskriptif analitik. Data diperoleh dengan menggunakan format inventarisasi data dengan mengunakan tabel. Data yang diambil tentang "citra perempuan" dalam kaba Anggun Nan Tungga. Pengumpulan data, menganalisis data dan pada akhirnya menjadi hasil laporan penelitian (Moleong, 2005:121).
Sumber data adalah kaba Anggun Nan Tungga karya Ambas Mahkota yang diterbitkan oleh Balai Buku Indonesia tahun 1982. Terdiri atas sembilan subjudul dengan jumlah halaman sebanyak 135 halaman. Sampul buku berlatar putih serta di bagian tepi atas dan bawah terdapat ukiran yang bernuansa Minangkabau.

Pendekatan utama yang dipergunakan untuk menganalisis permasalahan adalah pendekatan dari M.H. Abrams (dalam Teeuw, 1994: 50), yaitu pendekatan objektif sastra yang menitikberatkan pengkajian pada karya sastra itu sendiri. Dengan mengkhususkan perhatian pada teks sastra, unsur di luar karya sastra seperti pengarang dan realita objektif di kesampingkan.

Berikut dikemukakan beberapa pendapat yang berkaitan dengan asal-usul dan pengertian kaba. Kata kaba berasal dari khabar bahasa Arab yang berarti pesan atau berita. Dalam sastra tradisional Minangkabau, kaba biasa disebut curito yang artinya cerita (Abdullah, dalam Udin, 2006:14). Kata khabar berubah dalam ucapan Minangkabau menjadi kaba. Dalam perkembangan berikutnya kaba disebut juga curito.

Sesuai dengan hakikatnya sebagai sastra cerita, kaba mengungkapkan kehidupan manusia dengan segala persoalannya (Junus, 1994:2). Masyarakat Minangkabau sendiri beranggapan bahwa kaba menceritakan suatu peristiwa yang benar-benar terjadi. Sejalan dengan premis Junus tersebut, Udin (2006:16) menyatakan pula bahwa kaba sebagai berita kebenaran tentulah memberi manfaat bagi kehidupan masyarakat, mengangkat ajaran yang menyampaikan nilai dan sangat berguna bagi semua anggota masyarakat.

Dalam penelitian yang dilakukan Jamil Bakar (1989:12) ternyata terbukti adanya hubungan cerita kaba dengan keadaan masyarakatnya. Masyarakat Minangkabau hidup di negeri yang penuh kaba, yang ditimba dari tata nilai perikehidupan tradisional, tetapi tetap memekar di tengah kehidupan masyarakat yang nontradisional. Kaba bertahan hidup karena memang dibutuhkan masyarakatnya, sedangkan masyarakat pun menghidupkannya dan menghidupi kaba sebab kaba bagaikan bagian dari kehidupan mereka.

Navis (1986:243) menyatakan bahwa dalam bahasa Sanskerta kaba berarti senda gurau atau perlipur lara. Selanjutnya menurut Junus (1994:18), kaba bertugas untuk mendidik pembacanya bagaimana hidup bermasyarakat dan berbudaya. 
Djamaris (2002:78) mendefinisikan kaba sebagai cerita prosa berirama, berbentuk narasi (kisahan), dan tergolong cerita panjang. Dari segi isi cerita, $k a b a$ ini sama dengan hikayat dalam bahasa Indonesia lama atau novel sastra Indonesia modren. Selanjutnya, Junus (1994:17) mengungkapkan bahwa kata kaba sama dengan 'kabar', sehingga boleh juga berarti 'berita'. Kaba berbentuk prosa lirik, bentuk ini tetap dipertahankan apabila diterbitkan dalam bentuk buku. Kesatuan dalam kaba bukan kalimat dan bukan baris. Kesatuannya ialah pengucapan dengan panjang tertentu yang terdiri dari dua bagian yang berimbang.

Selanjutnya, Djamaris (2002:78) menjelaskan bahwa kaba tergolong ke dalam sastra lisan (oral literature), suatu karya sastra yang disampaikan secara lisan dengan didendangkan atau dilagukan yang ada kalanya diiringi dengan alat musik saluang atau rabab. Cerita kaba dengan mudah dapat didendangkan karena gaya bahasa yang digunakan dalam kaba adalah bahasa prosa berirama. Pola kalimat dalam kaba terdiri atas gatra dengan jumlah suku kata yang relatif tetap. Biasanya masing-masing gatra terdiri atas delapan suku kata, kadang-kadang delapan atau sepuluh. Konsistensi jumlah suku kata itulah yang memungkinkan timbulnya irama di dalam bahasa kaba, seperti halnya metrum yang menimbulkan irama pada sebuah lagu.

Menurut pendapat Kartono, citra perempuan sebagai pribadi terbagi atas empat macam, yaitu: (1) citra perempuan penyayang, citra perempuan penyabar, citra perempuan lemah lembut dan citra perempuan yang memiliki orientasi hidup. Kata kasih sayang menurut Sugono (2008:1234) adalah perasaan sayang yang diberikan kepada orang yang disayangi. Citra perempuan penyabar adalah sifat yang cenderung menerima saja dan memilih pola tingkah laku yang lebih baik mengalah (Kartono, 2007:17). (3) Citra perempuan lemah lembut adalah orang yang mempunyai budi bahasa yang lembut. Menurut Kartono (2007:17), sifat lemah lembut adalah salah satu yang mengukur keindahan psikis perempuan. Citra Perempuan sebagai anggota masyarakat dalam kaba terbagi atas dua bagian, yaitu citra perempuan dalam hubungan dengan keluarga dan lingkungan sekitar dan citra perempuan dalam kepedulian terhadap keluarga dan lingkungan sekitar. Mengenai citra perempuan dalam hubungan dengan lingkungan sekitar, menurut pendapat Kartono (2007:277), bahwa hubungan dengan lingkungan berarti penyesuaian diri dengan lingkungan merupakan tujuan hidup setiap manusia di dunia. Citra perempuan dalam kepedulian terhadap lingkungan/orang lain. Kepedulian adalah sikap perhatian atas penderitaan orang lain (Sugono, 2008:1036).

Usaha untuk mendeskripsikan citra tokoh perempuan tidak mungkin dapat dilakukan tanpa terlebih dahulu mendudukkan pengertian citra. Arti citra menurut Kamus Besar Bahasa Indonesia (2008:702) adalah (1) rupa; gambar; gambaran; (2) gambaran yg dimiliki orang banyak mengenai pribadi, perusahaan, organisasi, atau produk; (3) kesan mental atau bayangan visual yang ditimbulkan oleh sebuah kata, frasa, atau kalimat, dan merupakan unsur dasar yang khas dalam karya prosa dan puisi; (4) data atau informasi dr potret udara untuk bahan evaluasi; Dalam penelitian ini, yang dimaksud dengan citra adalah gambaran yang dimiliki orang banyak mengenai pribadi, perusahaan, organisasi, atau produk (Sugono, 2008:270). Sementara itu, citra perempuan adalah gambaran atau ciri khas perempuan. Perempuan yang selalu ditampilkan dalam karangka hubungan yang sama dan sebanding dengan seperangkat tata nilai yang berakhir pada kedudukan terbawah lainnya, yaitu sentimentanitas, perasaan, dan spiritual. Hal itu dapat dilihat dari penilaian prilaku sehari-hari.

Mengenai teori Filsafat manusia, Muhardi (2000:vi) mengatakan bahwa pola dasar sikap manusia berbudaya ditentukan oleh aspek yang berkaitan dengan persoalan psikofisik, yaitu (a) pandangan hidup, (b) tanggung jawab, (c) cinta kasih, (d) keadilan, (e) penderitaan, dan (f) citacita.

Usaha untuk mendeskripsikan citra perempuan dalam kaba Minangkabau itu dilakukan dengan melihat sikap, dan tingkah laku tokoh tersebut ketika berhadapan dengan konflik; bagaimana ia menghadapi permasalahan, bagaimana pandangan hidupnya, cita-citanya, dan konsepsi kehidupannya. Hasil tersebut dapat digeneralisasikan pada akhirnya sebagai citra dan di dalam penelitian ini dinyatakan sebagai kepribadian. 


\section{Pembahasan}

\section{a. Citra Tokoh Perempuan dalam Kaba}

\section{Anggun Nan Tungga Karya Ambas Mahkota}

Kaba Anggun Nan Tungga menceritakan tentang masyarakat yang hidup pada zaman tempo dahulu atau masyarakat tradisional. Membicarakan citra tokoh perempuan, akan dibahas dua aspek citra perempuan, yaitu citra perempuan sebagai pribadi dan citra perempuan sebagai anggota masyarakat dengan menggunakan teori Psikologi Wanita, Psikologi Umum, dan Flsafat Manusia. Berikut ini citra perempuan dibahas dari tokoh perempuan dalam Kaba Anggun Nan Tungga.

\section{b. Citra Perempuan Penyabar dan Memiliki Orientasi Hidup (Tokoh Ganto Pamai)}

Kehadiran Ganto Pamai hanya disebutkan pada bagian awal kaba Anggun Nan Tungga. Ganto Pamai meninggal dunia setelah melahirkan anaknya Anggun Nan Tungga Magek Jabang. Tetapi kehadiran Ganto Pamai yang sejenak itu mempunyai arti yang sangat penting dan dapat diidentifikasi secara sempurna.

Menurut Muhardi (1984:59), penderitaan pada dasarnya telah menjadi bagian dari diri manusia. Penderitaan akan selalu ada di mana pun manusia berada, dalam bidang apa pun yang dihadapi dan dikerjakan manusia. Oleh karena itu. sangat tepat bila konsep itu dihubungkan dengan penderitaan Ganto Pamai. Penderitaan itu sudah menjadi kodrat manusia, dan ia harus dihadapi. Pada posisi itulah Ganto Pamai berada.

Pertama, secara kodrati manusia adalah makhluk yang harus menghadapi penderitaan. Cara menanggung penderitaan pada setiap orang berbeda-beda. Tidak ada jalan keluar dari kenyataan bahwa penderitaan adalah sesuatu yang harus ditanggung oleh dirinya sendiri. Kesabaran Ganto Pamai dalam kaba Anggun Nan Tungga terlihat sejak Ganto Pamai hamil. Secara fisik memang dia sangat tersiksa, sampai pada saat akan melahirkan. Penderitaan bagaikan akrab dengannya. Sejak anaknya lahir, Ganto masih terus menanggung derita sebelum akhirnya meninggal dunia. Konsep penderitaan menurut Niezsche seperti disilir Fuad Hasan (dalam Muhardi, 2000: 62) sedemikian melekat dalam diri Ganto Pamai. Menghindarkan diri dari penderitaan bukanlah dengan menjauhi penderitaan itu secara lahiriah, tetapi dengan jalan mendekati penderitaan itu.

Sementara

itu, menurut teori eksistensialisme yang dipelopori Bardeyaev, seperti dikutip Fuad Hassan (dalam Muhardi, 2000:15) dikatakan bahwa manusia adalah makhluk yang kompleks dan ditandai oleh dualisme dasar yang tidak dapat disangkal, yaitu di satu pihak manusia adalah makhluk Tuhan dan di lain pihak manusia adalah produk alamnya. Jadi, manusia itu berstatus sebagai mahkluk spiritual dan merupakan bentukan alamiah, dan kedua segi ini menjadi satu sebagai pribadi individual.

Sikap (attitude) Ganto Pamai apabila dihubungkan dengan teori tadi dapat disimpulkan bahwa tokoh itu sadar bahwa Tuhan merupakan suatu kekuatan yang mutlak. Tuhan berkuasa terhadap segalanya. Hal itu dibuktikan dengan sikap Ganto Pamai dibarengi pula oleh penyerahan diri secara total kepada Tuhan. Citra tentang orientasi hidup terlihat pada saat penyerahan diri seutuhnya kepada Tuhan. Ganto Pamai menerima nasib dengan tawakal. Hal itu dapat kita lihat dalam kutipan berikut.

Tentang halnya Ganto Pamai, ia bertambah sakit jua, sakit bagaikan membawa lalu, rintang mengeluh mengerang panjang, sakit anggota tubuh semuanya, ngilu segala persendian, gila menghempas-hempas badan, menghempas ke kiri menghempas ke kanan, air mata berderai jua. (Anggun Nan Tungga, 1982:9)

Sedang di badan diri saya, sakit tidak kepalang tanggung, rasakan sampai ajallulah, gerak telah tiba, janjian telah sampai, maafkanlah badan saya ini, kalau ada kata yang terdorong, kalau ada salah dengan khilaf, maafkalah semuanya itu. (Anggun Nan Tungga, 1982:9)

Kedua, dalam diri Ganto Pamai muncul sebersit keinginan dari dasar hatinya, begitu dia menyadari ajal telah mendekat. Keinginan itu berhubungan dengan sesuatu yang selama ini belum didapatkan dan Ganto Pamai. Keinginan Ganto Pamai identik dengan harapan seperti yang dikemukakan Muhardi (2000:66), yaitu idealisme

"Citra yang memiliki orientasi hidup terlihat disaat Penyerahan diri seutuhnya kepada Tuhan itu membuat menerima nasib dengan tawakal. 
di luar realitas sebenarnya. Harapan tersebut dapat berupa konsep ideal karena ketidakpuasan terhadap realitas.

Menurut Taufik Abdullah (dalam Muhardi, 2000:15) pandangan hidup merupakan faktor utama dalam pembentukan sikap dan pola tingkah laku manusia. Pandangan hidup membentuk manusia mengolah sikap dan kepercayaan. Pandangan hidup yang diyakini akan memberi warna tertentu pada pola sikap seorang manusia.

Berkaitan dengan Ganto Pamai, pandangan hidup menurut Kluckholm seperti yang diuraikan Koetjaraningrat (dalam Muhardi, 2000:19) diimplikasikannya dalam kehidupan. Ganto Pamai memiliki pandangan hidup yang ideal. Orientasi budaya manusia yang ideal adalah manusia yang memandang hidup itu buruk, tetapi berusaha untuk mewujudkan supaya hidup itu menjadi baik. Memandang hidup itu buruk sebagai landasan untuk mewujudkan kehidupan di masa datang yang lebih baik. Dengan demikian, berkarya, berbuat, bersikap maju tidak henti-hentinya, menjadi alasan untuk memperbaiki masa lalu.

Citra yang memiliki orientasi hidup juga terlihat di saat Ganto Pamai sadar benar bahwa malu sudah melekat di kening keluarga mereka. Sebagai keturunan Rajo Tuo yang memerintahkan Tiku Pariaman, Ganto Pamai sudah kehilangan kekuatan yang dibanggakan, yaitu tiga saudara laki-lakinya: Mangkudun Sati, Nangkodo Rajo, dan Katik Intan. Ketiganya hilang tidak tahu rimbanya, menyusul keberangkatan mereka dari Tiku Pariaman untuk berniaga. Kehilangan ketiga saudara laki-lakinya sekaligus, bagi Ganto Pamai berarti runtuhnya "pagar" kampung dengan kota. Dalam budaya Minangkabau, eksistensi saudara laki-laki benar-benar ditonjolkan. Adat memberikan banyak kewajiban kepada saudara laki-laki. Selain itu, kepentingan saudara keluarga yang saparuik (seperut) kelompok yang lahir dari garis ibu diperhatikan, juga bertanggung jawab atas kelangsungan perkembangan seseorang anggota keluarga. Dalam hubungan itu, kenyataan itu tidak didapatkan Ganto Pamai. Anaknya lahir, tetapi mamak (paman) tidak ada. Mengenai implikasi keinginannya itu, dia menyatakan kepada kerabat dekatnya yang lain, seperti Suto Suri, Kambang Nan Baduo, dan Bujang Nan Salamat. Dengan menyatakan keinginan itu, Ganto Pamai berharap keinginannya akan terwujud dikemudian hari. Hal itu dapat kita lihat dalam kutipan berikut ini.
Kepada adik kandung Suto Suri, kepada kembang keduanya, serta Bujang Salamat, dekat-dekatlah duduk kemari ada yang hendak saya katakan. Tentang anak kandung saya telah selamat sampai kedunia Yaitu Tungga Magek Jabang, yang bergelar Magek Duraman, senang rasa perhatian. (Anggun Nan Tungga, 2007:9)

Juga kepada kamu Bujang Salamat, peganglah amanat saya ini andaikan sampai si Tungga dewasa dia jangan kamu sia-siakan, kamu yang jadi tangan kanan, kamu yang menjadi tongkat berjalan, peganglah amanat kuat-kuat, buhul di dalam ikat pinggang, sekali jangan dilupakan. (Anggun Nan Tungga, 1982:10)

Ketiga, Ganto Pamai ternyata masuk kedalam barisan wanita yang merana. Orang di Minangkabau dikuasai oleh dua hal: adat dan syara (agama). Lazimnya orang Minangkabau adalah fanatik sehingga begitu agama membolehkan seorang laki-laki mempunyai sebanyak-banyaknya empat orang isteri, "hak" istimewa itu kemudian memang dipergunakan dengan sebaik-baiknya oleh laki-laki. Mungkin tidak ada tempat lain yang begitu banyak penganut poligaminya, tidak ada tempat lain begitu banyak terdapat kaum wanita yang merana. Perasaan sabar yang dimiliki Ganto Pamai terlihat juga ketika Ganto Pamai tidak mempertotonkan kesedihannya, kendati begitu lama ditinggalkan Tuanku Haji Ledang, bahkan Ganto Pamai begitu pandai menyembunyikan duka citanya, sampai ia juga tidak mengetahui Tuanku Haji Mudo kawin lagi dengan Galingga, Layua di ranah Koto Dalam.

Berdasarkan identifikasi tadi, pembicaraan tentang tokoh Ganto Pamai akan sampai pada teori Kathleen Googh seperti disilir Arief Budiman (1999:24) yang menyatakan bahwa di dalam masyarakat matrilineal, laki-laki merupakan orang yang memegang kekuasaan sebagai kepala keluarga, kepala marga dan kepala masyarakat sementara itu perempuan hanya bisa menjalankan kekuasaan melalui pamannya, sehingga anak laki-laki yang sudah dewasa kelak juga akan bertanggung jawab terhadap kemenakan dari saudara perempuan.

\section{c. Citra Perempuan Penyayang (Tokoh Suto Suri)}

Menurut Brunetta R. Wolfman (1999:55) ada sementara perempuan yang mengambil 
keputusan tidak menikah dan hidup sepenuhnya sebagai perempuan jalang. Mereka menentukan itu walaupun ada tekanan yang menentang dan berpendapat bahwa hidup tidak harus dihayati secara berpasangan. Namun, banyak juga dari kelompok perempuan itu tidak berikrar hidup sendiri seumur hidup, melainkan tetap terbuka untuk kawin, kalau mereka inginkan, pada suatu waktu di masa mendatang.

Muhardi (2000:40) menyatakan bahwa tanggung jawab terhadap diri sendiri menjadi dasar pertanggung jawaban setiap manusia. Rasa tanggung jawab terhadap diri sendiri, pada akhirnya berkembang menjadi rasa tanggung jawab terhadap keluarga sendiri, terhadap masyarakat, terhadap kelompok, daerah atau bangsa sendiri. Sehubungan dengan itu, Suto Suri termasuk ke dalam golongan perempuan yang diklasifikasikan tersebut. Akan tetapi, motivasi pilihan itu lebih disebabkan rasa tanggung jawab kepada kakaknya Ganto Pamai. Citra perempuan penyayang yang dimiliki tokoh Suto Suri tertuju pada kakaknya terlihat ketika Suto Suri diwujudkan dengan memelihara dan mendidik Tungga Magek Jabang, anak kakaknya itu. Pada titik itu perannya pun berubah menjadi seorang ibu kendati ia tidak pernah mempunyai seorang suami. Suto Suri memang menghayati penderitaan kakaknya dan tahu betul apa yang akan dilakukannya begitu Ganto Pamai meninggal dunia. Dia kini harus mampu beridiri sendiri dalam suasana sebagai ibu. Ikatan efektif yang lama ketika Ganto Pamai dan saudara laki-lakinya masih berada di Tiku Pariaman, sudah banyak yang dilepaskan. Suto Suri kemudian menciptakan relasi emosional yang baru sebagai tuntutan oleh adanya peran baru yang diembannya.

Pada pelepasan ikatan emosional yang lama itu, fungsi identifikasi menurut Kartini Kartono (2007:67) berperan penting sekali. Objek cinta kasih lama mengalami peninjauan kembali, dan mengalami proses devaluasi. Suto Suri telah menemukan identifikasi dengan objek baru yang dianggapnya bernilai dan lebih berarti daripada yang lama. Kehadiran Tungga Magek
Jabang, membuat Suto Suri berusaha keras untuk beradaptasi terhadap tanggung jawab barunya. Dia hidup sangat respek terhadap kondisi itu karena dianggap lebih memenuhi selera hatinya. Akibatnya, berlangsunglah suatu devaluasi untuk menggantikan objek afeksi yang lama. Pada gilirannya dia mencurahkan kasih sayang kepada Tungga Magek Jabang secara konkret sampai dia dewasa dan bertanggung jawab terhadap anak saudara perempuannya.

\section{d. Citra Perempuan Memiliki Orientasi Hidup (Tokoh Kambang Alamsani)}

Tidak berbeda dengan kambang yang telah dianalisis sebelumnya, Kambang Alamsani kurang lebih juga memiliki sifatyang sama dengan Kambang yang lain. Dengan sifatnya yang cepat kaki ringan tangan, Kambang Alamsani memperlihatkan sikap tanggung jawabnya terhadap keluarga Suto Suri. Sejak Ganto Pamai masih hidup sampai Tungga Magek Jabang lahir dan tumbuh dewasa, Kambang Alamsani mengabdikan dirinya kepada keluarga itu. Hal itu adalah sebagai konsekuensi pilihan hidupnya dari sekian banyak alternatif yang diberikan kepadanya.

Menurut Muhardi (2000:38), manusia bertanggung jawab terhadap diri sendiri. Dia bertanggung jawab untuk membentuk pribadinya. Manusia pada hakikatnya bebas memilih jalan dan cara bagaimana yang akan ditempuhnya. Pada prinsipnya ajaran agama hanyalah memberikan alternatif bagi manusia untuk memilih yang baik atau yang buruk. Akan tetapi, dibalik kebebasan yang dimilikinya, dia harus bertanggung jawab terhadap pilihannya itu. Orang lain tidak dapat ikut mempertanggungjawabkannya.

Citra yang memiliki orientasi hidup terlihat ketika Kambang Alamsani (dan juga seorang kambang lain yang namanya tidak disebutkan di dalam kaba) telah mempergunakan kebebasan dan kemerdekaan untuk menentukan pilihannya sendiri. Seperti telah dikemukakan sebelumnya, tanggung jawab terhadap diri sendiri menjadikan dasar pertanggungjawaban setiap manusia.

\section{" ...bagi manusia tanggung jawab yang utama adalah terhadap diri sendiri, ia bertanggung jawab untuk membentuk pribadinya, manu- sia pada hakikatnya bebas memilih jalan dan cara bagaimana yang akan ditempuhnya."}


Rasa tanggung jawab terhadap diri sendiri itu pada gilirannya akan berkembang menjadi rasa tanggung jawab terhadaop kelompok, seperti yang dimanifestasikan Kambang Alamsani terhadap keluarga Suto Suri.

\section{e.Citra Perempuan Penyayang (Tokoh Mande Ameh Manah)}

Dunia perempuan memang sangat khas dengan segala tingkah lakunya. Dunia perempuan punya skema dasar dan struktur dasar tertentu dari tingkah lakunya. Dunia perempuan itu khas menampilkan diri sebagai dunia yang memeliharanya, yang menurut Kartini Kartono (2007:3) sebagai besorgend welt.

Dunia besorgend welt dari kaum wanita itu sendiri menurut Kartini, berpangkal pada kehadiran seorang bayi. Dengan penghayatan pada kehadiran Tungga Mageklah, Mande Ameh Manah kemudian mengembangkan dinamika adaptasi pada situasi baru untuk menyesuaikan diri. la mengembangkan dinamika adaptasi pada situasi baru untuk menyesuaikan diri. la mengembangkan pola tipe keperempuanan dan khas keibuannya kepada Tungga Megek Jabang.

Sedangkan yang menarik pada pribadi Mande Ameh Manah adalah ia mampu keluar dari egoismenya. Citra perempuan penyayang yang dimiliki tokoh Mande Ameh ketika la mampu berkomunikasi dengan landasan persahabatan, simpati dan cinta kasih terhadap Tungga Magek Jabang, kendati bukan anak kandungnya sendiri. Menurut Karyini (dalam Muhardi, 2000:9) hakikat wanita hanya berkembang di dalam kontak dengan pribadi lain. Jadi wanita adalah pribadi sosial, yaitu pribadi psikifisik yang memerlukan antar relasi jasmaniah dan psikis dengan manusia lain.

Oleh ciri yang "besorgend welt" di atas, Mande Ameh Manah cenderung bersifat heterosentris, yaitu lebih menyerahkan diri kepada pribadi lain. Totalitas penyerahan diri kepada pribadi lain ini dapat dikatakan sebagai kekuatan yang sangat hebat dan dahsyat, karena segenap eksistensinya dilimpahkan kepada orang yang dicintainya, yakni Tungga Magek Jabang. Ini diketahui setelah belakangan disebutkan bahwa sesungguhnya Tungga dan Gondoriah merupakan saudara sepersusuan.

\section{f. Citra Perempuan Lemah-Lembut dan Memiliki Orientasi Hidup (Tokoh Gondan Gondoriah)}

Di dalam kaba Anggun Nan Tungga itu disebutkan bahwa Gondan Gondoriah adalah tunangan Tungga Magek Jabang sejak di dalam kandungan. Di dalam adat Minagkabau artinya Gondoriah pulang ke "bako", saudara perempuan pihak bapak. Tungga Magek Jabang disebut pulang ke anak "mamak" (paman), saudara laki-laki pihak ibu. Keduanya akhirnya memang tidak jadi kawin, setelah bapak Tungga Magek Jabang, Tuanku Haji Mudo yang bertarak (bersemedi) di gunung Ledang membuka rahasia "persaudaraan" antara Tungga dan Gondoriah.

Menyitir pertanyaan Kartini Kartono (2007:5) eksistensi peremuan mencakupi cara dia menghayati dan menyadari hakikat dirinya dan makna pribadinya antara lain memahami relasi dirinya dengan dunia sekitar, dengan segala isinya, dan dengan sesama manusia.

Selanjutnya Kartini menyatakan bahwa adanya pribadi perempuan di dunia harus diartikan ada bersama (sein ist meitsein), yang mengandung komunikasi dengan manusia lain. Tanpa adanya manusia lain, perempuan tidak akan bisa mengembangkan serta menyempurnakan dirinya. Karena itu eksistensi perempuan sebagai menusia adalah hidup bersama dengan subjek lain (Kartini Katrtono, 2007:7).

Substansi (kemandirian) Gondan Gondoriah dalam pengertian antologis, bagian dari matafisika yang membicarakan eksistensi dan segala ciri atau sifatnya, dapat di interprestasikan sebagai pribadi yang berpendirian dan mampu memilih sendiri berdasarkan kebutuhan. Gondoriah dengan tegas menolak pinangan Malin Cik Amen yang berkhianat terhadap Tungga Magek Jabang, karena dia sadar dirinya memiliki otonomi untuk senantiasa menunggu kedatangan Tungga Magek Jabang. Instingnya memberi isyarat bahwa sesungguhnya Tungga masih hidup dan pasti kembali kepadanya. Hal itu dapat dilihat pada kutipan berikut ini.

"Dibujuklah anak kandung, dibulatkan faham makrifat, tibalah gerak dari Allah, tibalah wahyu dari Nabi, sedikitpun ia tidak percaya, tuan Tungga telah hilang, sejak kecil masak dengan pengajaran, sudah dewasa akan tiba, ayah kandung keramat, yang bertarak di Gunung Ledang, tidak mungkin ia seperti itu, sedangkan tuan juru mudi, dia hidup kembali pulang, apalagi tuan Tungga, berdua 
dengan Bujang Selamat, orang keramat yang hidup, sebab mengapa demikian, dilihat rantau semuanya, jaranglah orang tandingannya, hanya sebuah yang terjadi ada udang dibalik batu, ada kusut yang tidak selesai, nanti orang akan tahu juga. Sebab mengapa demikian, adat hidup bertunangan, sejak di rahim ibu kandung, gerak dan gerik tentu datang, andaikan Tungga hilang di laut, kalau sampai janjian mati, malang dan sakit andaikan datang, surat sepucuk tentu tiba, kalau tidak dari Anggun Tungga, tentu dari Bujang Selamat, kalau tidak dipesan dengan orang, dalam mimpi akan datang juga. Kini telah lama Tungga pergi, mimpi tidak ada yang buruk, igauan tidak ada yang salah, baik tanda semuanya, berdusta rupanya juru mudi, buruk siasat tuan nahkoda". (Anggun Nan Tungga, 1982: 67)

Selain itu hakikat perempuan hanya dapat berkembang di dalam kontak dengan individu lain, karena perempuan juga bagian dari pribadi sosial, yaitu pribadi psikofisik yang memerlukan antar relasi jasmaniah dan psikis dengan manusia lain. Perempuan juga ingin dicintai, ingin dihargai dan diakui, ingin dihitung dan mendapatkan status di dalam kelompoknya. Dalam komunikasi dengan individu lainlah perempuan bisa berkembang dan melengkapi dirinya.

Seorang ahli filsafat Karl Jaspersz, seperti dikutip Kartini Kartono (2007:10) menyatakan bahwa adanya aku cuma ada bersama engkau. Ich bin nur in komunikation mit den Andern. Dengan demikian hidup itu berdialog dengan sesama manusia, yang disebut sebagai ein dialogisches leben. Dengan berdialog, manusia dan juga perempuan dapat membangun dirinya, membangun dunia serta kebudayaanya.

Gondan Gondoriah merasa perlu menemui Tungga Magek Jabang di atas kapal Dandang Panjang menjelang kepergiannya mencari mamaknya (pamannya) yang hilang, karena sebagai perempuan ia hanya akan dapat menikmati kesempurnaannya dengan ada bersama subjek lain, yaitu Tungga Magek Jabang. Dia akan merasa dirinya bermakna dan berarti sebagai realita di dunia, bilamana ia berguna dan berarti bagi Tungga Magek Jabang.

Citra perempuan lemah lembut adalah salah satu yang mengukur keindahan psikis perempuan. Sifat lemah lembut terlihat pada saat Gondoriah berikrar di depan tunangannya itu, apabila Tungga berkhianat ia akan pergi ke gunung (Ledang). Hal ini dapat dilihat sebagai kebutuhan psikis
Gondoriah untuk ada bersama-sama dengan pribadi lain. Pribadi lain itu merupakan consubject merupakan partner atau teman berdialog, yang oleh Heidedeger seperti dikutip Kartini Kartono (2007:10) disebut sebagai Des leben ein dialogische leben, hidup itu merupakan hidup dialogis; memerlukan kontak dengan orang lain, bertukar pikiran, memberi dan menerima simpati untuk kerja sama guna membangun keakuannya. Hal itu dapat dilihat pada kutipan berikut.

Bersumpah Gondo disana, janji kemudian ia buat, sumpah kalau diingkari Tungga, Gondo akan menghindar pula, sumpah kalau diingkari Gondo, Tungga akan melepas pula, begitu saksi bunyi sumpah, bersaksi orang dalam Dandang (kapal), orang yang tiga ratus, yaitu di banda kuala, ialah di kuala Banda Teleng, sumpah yang sangat dalam, sumpah yang digantung tinggi. (Anggun Nan Tungga, 1982:42)

Jadi, seorang perempuan selalu punya posisi bersama-sama dengan pribadi lain, dalam hal itu laki-laki. Oleh karena itu, kemunculannya sebagai "pribadi" dimungkinkan oleh kesatuannya dengan pribadi lain. Hal itu menyebabkan Gondoriah merasa hidupnya akan berarti apabila dia "berada" di dalam diri Tungga Magek Jabang. Sebaliknya, apabila perpisahan berlangsung, Gondoriah sendiri tidak mengetahui bagaimana nasib dirinya. Hal itu dapat dilihat pada kutipan berikut.

Tuan saya Magek Jabang, dengarkan jugalah oleh tuan, andaikan hilang tuan masuk laut, andaikan tuan karang oleh gelombang, badan saya bagaimana nantinya. (Anggun Nan Tungga, 1982:41)

Hakikat dari kehidupan sosial atau hidup bersama seperti yang diidamkan oleh Gondan Gondoriah ialah tumbuhnya kebersamaan dalam ruang interpersonal. Dengan pola dasar dan grundvormen tertentu, Gondoriah menciptakan ruang hidup bersama tunangannya Tungga Magek Jabang.

Selain itu, perempuan punya bermacam bakat dan potensi untuk merealisasi dirinya sepanjang hidupnya. Selanjutnya dia selalu memperjuangkan eksistensi dirinya secara khusus manusiawi. Dalam keberadaannya di dunia, dia punya hubungan tertentu dengan realitas.

Gondoriah berusaha mengatasi dirinya sendiri dengan kemampuan penghayatan yang dimilikinya, bahkan dia juga berupaya menanamkan cita-cita dan harapannya menuju hari esok yang lebih baik. 
Citra yang memiliki orientasi hidup terlihat ketika Gondan Gondoriah juga termasuk tipe perempuan ideal yang mampu merencanakan tujuan yang berdimensi jauh ke depan di dalam lingkungannya. Dia ingin terus maju di atas kurva biologisnya. Dia juga tumbuh dan eksis di dalam ruang interpersonal perempuan yang punya makna tertentu. Paling tidak di mata Tungga Magek Jabang.

\section{g. Citra Perempuan Memiliki Orientasi Hidup (Tokoh Kambang Malang, Bungo Inai, Bungo Pimpiang, dan Kambang Bungo Cino)}

Pada bagian deskripsi tokoh perempuan disebutkan bahwa kehadiran mereka di dalam kaba Anggun Nan Tungga cenderung sebagai pelengkap cerita sehingga tidak begitu ditonjolkan.

Berdasarkan identifikasi dan interprestasi kambang sebelumya, citra mereka kurang lebih juga sama, yaitu memiliki citra tentang orientasi hidup hal ini dimungkinkan oleh kualitas mereka sebagai kambang pada keluarga Gondan Gondoriah yang tidak berbeda dengan kambang yang lahir.

\section{h. Citra Perempuan Memiliki Orientasi Hidup (Tokoh Andami Sultan)}

Di dalam kaba itu, ternyata Puti Andami Sutan kawin dengan Tungga Magek Jabang. Padahal Tungga sudah bertunangan dengan Gondan Gondoriah di Tiku Pariaman. Realitas seperti itu memberikan gambaran bahwa pada diri perempuan mana saja terdapat semacam "kharisma" dan daya tarik yang mampu melumpuhkan laki-laki. Hal itu tidak akan dapat diingkari karena kekhasan hampir semua wanita di dunia adalah kelembutan.

Solovjev seorang filsuf Rusia, seperti Franz Dahler (dalam Muhardi, 2000:31) menyatakan bahwa jika seorang jatuh cinta secara serius, dia terlempar keluar dari cinta diri. Dia mulai hidup untuk orang lain. Hal yang sama berlaku juga pada diri Puti Andami Sutan, yang saling jatuh cinta dengan Tungga Magek Jabang. Bersamaan dengan itu, menyusul datang Tungga yang hendak menemui mamaknya (pamannya) Mangkudun Sati, ayah Puti Andami Sutan. Hal itu dapat dilihat pada kutipan berikut.
Datanglah kemudian Andami Sutan, diiringi si kambang yang bertiga, wajah yang merah kemalu-maluan, maklum muda sama muda, terkecoh hati tuan Tungga, melihat wajah Andami Sutan, berdesir darah Andami. (Anggun Nan Tungga, 1982:79)

Dalam pertemuan yang tanpa diduga sebelumnya itu, terjadilah kontak antara Tungga dan Andami Sutan, yang pada gilirannya saling membuka hati dengan jujur. Menurut Muhardi (2000:29), kontak yang terjadi dalam pertemuan tidak dapat dinyatakan karena kontak itu dikhususkan untuk kedua orang yang saling bertemu dalam situasi hidupnya yang tertentu. Akibatnya, bahwa setiap pertemuan merupakan sesuatu yang unik dan tidak diulangi kembali. Andami Sutan mengakhiri pertemuan itu justru melalui ikatan perkawinan, menyusul permintaan Tungga untuk memperoleh burung Nuri pintar bicara miliknya.

Meskipun secara tersirat didapati gejala bahwa perkawinan itu didasari oleh kemungkinan yang lain, cinta yang mengingat Tungga dan Andami Sutan telah merangkum eksistensi mereka. Bukankan cinta tidak dapat dipaksa? la timbul dan berkembang secara spontan saja.

Kedua orang yang saling mencintai tetap mempertahankan individualitasnya, sehingga tetap ada kemungkinan untuk melepas hubungannya dan memilih kembali ke jalan hidupnya sendiri (Muhardi, 2000:38). Hal itu dapat dilihat pada kutipan berikut.

Setelah lama di rantau orang, banyak
penderitaan yang dicoba, sudah habis hari
berganti hari, hari berganti dengan pekan,
pekan sudah menjadi bulan, bulan sudah
menjadi tahun pula. Datang ingatan masa
itu, tergerak hati akan pulang, yaitu ke Tiku
Pariaman, ibu kandung entah sudah sakit,
dengan kampung teringat pula, sesangkan
mamak (paman) yang dicari, mamak
bertiga bersaudara, sudah jelas hidup
matinya, begitu pula kehendak Gondo,
cukup lengkap semuanya, sataupun tidak
ada yang kurang, kehendak seratus dua
puluh. (Anggun Nan Tungga, 1982:91)

Hal itu terjadi pada diri Tungga Magek Jabang, yang pada akhirnya kembali ke Tiku Pariaman untuk memenuhi janjinya pada Gondan Gondoriah. Citra yang memiliki orientasi hidup terlihat ketika Puti Andami Sutan tidak mampu mencegah karena energi cinta dalam diri Magek Jabang telah 
mendorongnya untuk berbuat dan mengambil prakarsa.

\section{i.Citra Perempuan Citra Perempuan Memiliki Orientasi Hidup (Tokoh Santan Batapih)}

Pada mulanya Santan Batapih menanam harapan untuk dapat mendapatkan Tungga Magek Jabang. Tapi ia tidak berani meyampaikan rasa cintanya pada Tungga Magek Jabang. Santan Batapih hanya berbicara secara tersamar, tetapi selalu berusaha berdampingan dengan Tungga Magek Jabang. Untuk itu, dia memilih menjadi penunjuk jalan ke tempat Andami Sutan, sembari menyatakan kekhawatirannya kepada Tungga Magek Jabang. Hal itu dapat dilihat pada kutipan berikut.

Tuang Tungga yang saya hormati, sudah tampak Kualo Koto Tanau, kelihatan negeri Andami Sutan, putri cantik bukan kepalang, saya terlarut sekarang ini seperti kata pantun juga, baju beludru berhias emas, buatan anak orang Pariaman, hati berharap cemas, burung kok lepas dari tangan. (Anggun Nan Tungga, 1982:77)

Ternyata begitu sulit bagi Santan Batapih untuk menyadari peranannya sendiri. Sebagai seorang perempuan yang sudah dewasa dan memahami makna cinta, dia percaya bahwa perasaan itu merupakan dorongan alamiah dalam dirinya dan boleh saja terungkap dalam lingkungan sosial.

Menurut Carol Gilligan (dalam Barnhouse, 1998:45) perempuan cenderung mempersoalkan normal tidaknya perasaan mereka dan mengubah penilaian menjadi berbeda dari pendapat orang lain. Namun, dalam kaitan itu Santan Batapih telah menunjukkan identitasnya yang paling hakiki. Dia memiliki perhatian asasi terhadap hubungan antar manusia. Hal itu dapat dilihat pada kutipan berikut.

Kepada tuan kandung saya, tuan Tungga magek jabang, apakah sebabnya tuan termenung, apa yang menyusahkan dalam hati, ingatan tampaknya hilang-hilang timbul, sakit demam gerangan tuan, sakit terbawa dari Pariaman, dengarkanlah pantun saya, jika menebang batang kemuning, jangan diikat dengan daunnya, jika tuan ngilu pening, disini cari obat tawarnya. (Anggun Nan Tungga, 1982:76)

Citra yang memiliki orientasi hidup terlihat ketika akhirnya dia harus menelan kekecewaan karena Tungga Magek Jabang kawin dengan Andami Sutan, tetapi Sutan Batapih mencoba memberi makna terhadap gambaran kekecewaannya itu. Sementara itu, dia menikah dengan Katik Alamsudin, saudara seayah dengan Tungga. Dengan demikian, obsesinya tentang sosok Tungga Magek Jabang, dia refleksikan ke dalam diri Atik Alamsudin yang menjadi suaminya.

\section{j. Citra Perempuan Penyabar dan Lembut (Tokoh Puti Intan Korong)}

Secara riil tokoh itu tidak hadir di dalam kaba Anggun Nan Tungga. la hanya disebut sebagai adik Nagkodo Baha. Akibatnya, perilakunya tidak dapat diidentifikasikan secara sempurna, selain sebagai gadis yang sabar dan lembut. Dia dapat terungkap pada saat berlangsungnya sayembara untuk mencari jodoh, tidak ada respons yang muncul pada diri tokoh itu.

\section{k. Citra Perempuan dalam Hubungan dengan Keluarga dan Penyayang (Tokoh Galinggan Layua)}

Kata kasih sayang menurut Sugono (2008:1234) adalah perasaan sayang yang diberikan kepada orang yang disayangi. Tokoh itu hadir pada bagian ke-13 di dalam kaba ini. Citra perempuan dalam hubungan dengan keluarga terlihat ketika sebagai seorang ibu, dia punya naluri yang tidak berbeda dengan perempuan pada umumnya. Dia membimbing dan mendidik anaknya pada langkah pertama jalan hidupnya. Sebagai ibu, Galinggam Layua juga meletakkan dasar pertama untuk perkembangan selanjutnya dari akal dan budi anaknya Katik Alamsudin. Kemudian, selama waktu yang panjang Galinggam masih menjadi penuntun bagi Alamsudin dalam menempuh jalan hidup yang penuh kesukaran.

Akibatnya, ketika Alamsudin minta izin untuk pergi ke dalam rimba belantara guna memenuhi saran seorang dukun dalam kaitan soal jodohnya, Galinggam Layua tidak mampu membendung kesedihannya. Citra perempuan penyayang terlihat di saat cinta kasih pada anak satu-satunya sangatlah besar dan mendalam sehingga merasa khawatir dengan kepergian anaknya. Hal itu dapat dilihat pada kutipan berikut.

Dimintalah izin kerelaan ibu, yaitu ibu Galinggan Layua, berjalanlah Katik Alamsudin, berdua dengan Bujang Salamat 
yaitu Salamat Rangkayo Mudo, dibawa pula bedil pusaka, dibawa beras dengan bekal, serta jaro seharian. Tentang halnya ibu kandung, melihat anak akan berjalan, jatuh berderai air mata, rimba di mana akan dihadang, hutan mana akan diharu, berjalan bagaikan berhiba hati, kehendak yang tidak kunjung datang. (Anggun Nan Tungga, 1982:114)

Wujud dari kebahagiaan seorang ibu, diperlihatkan Galinggan Layua setelah anaknya mendapat jodoh. Dia menikmati kebahagiaan sebagai anugrah Tuhan, karena keresahan hatinya tentang calon isteri anaknya telah sirna dengan hadirnya utusan dari Tiku Pariaman yang memberitahu kedatangan Santan Batapih dan ayahnya dari Pulau Ranggeh Suri.

\section{Citra Perempuan dalam Hubungan dengan Lingkungan (Tokoh Niniak Kabayan)}

Cita-cita haruslah diusahakan dengan penuh kesadaran, dan setiap usaha menuntut kesediaan untuk bersusah payah, merangkak setahap demi setahap. Dalam hal itu diperlukan ketabahan, karena orang yang tabahlah yang dapat mencapai cita-citanya. Tanpa usaha dan tanpa kesediaan untuk bersusah payah menghadapi tantangan serta tanpa ketabahan, cita-cita tidak lebih dari sekadar angan-angan (Muhardi, 2000:70).

Niniak Kabayan selaku orang tua tetangga Gondoriah, menyadari benar atas keputusan tunangan Tungga itu. Dia dapat menerjemahkan kekecewaan Gondoriah yang telah dikhianati Tungga Magek jabang. Citra perempuan dalam hubungan dengan lingkungan sekitar terlihat pada saat Niniak Kabayan berupaya mencegah kepergian Gondoriah ke Gunung Ledang sebagai proyeksi sikap tanggung jawabnya terhadap anak gadis tetangganya itu. Meskipun di dalam kaba tidak disebutkan status Niniak Kabayan, secara implisit dapat diidentifikasi bahwa dia juga merupakan bagian dari masyarakat Tiku, sejorong (sewilayah) dengan Gondoriah. Artinya adalah, rasa tanggung jawab Niniak Kabayan berkembang menjadi rasa bertanggung jawabnya terhadap orang sekampung. Dia ikut bertanggung jawab untuk kelompok masyarakatnya, karena dia merasa ikut terlibat atau bagian dari kelompok masyarakatnya. Hal itu dapat dilihat pada kutipan berikut.

Ditebang tidak tertebang, bagaikan menebang papan kincir, digalang tidak tergalang, bagaikan menggalang air ke hilir, dilepaslah jadinya. (Anggun Nan Tungga, 1982:102).

Meski akhirnya Niniak Kabayan tidak mampu mencegah kehendak Gondoriah, dia sudah memperlihatkan sikapnya yang paling mutlak. Lepas dari pilihan sikap itu, kekuatan memang tidak berada pada dirinya. Niniak Kabayan pun pasrah.

\section{m. Citra Perempuan dalam Hubungan dengan Lingkungan (Tokoh Niniak Rang Paladang [Urang Manggoro])}

Tidak berbeda dengan Niniak Kabayan, tokoh Niniak Rang Paladang juga memperlihatkan sikap yang sama ketika menghadapi konflik Gondan Gondoriah. Citra perempuan dalam hubungan dengan lingkungan sekitar terlihat pada saat Niniak Kabayan berupaya mencegah niat Gondoriah pergi ke gunung Ledang. Sikap itu sebagai implikasi rasa kebersamaan dan sosialisasi yang besar dalam diri Niniak Rang Paladang.

Kepedulian adalah sikap perhatian atas penderitaan orang lain (Sugono, 2008:1036). Sesuai dengan kodratnya perempuan diberikan Tuhan perasaan yang lebih peka dari pada lakilaki. Kepekaan perasaan itulah yang membuat perempuan lebih mudah tersentuh akan penderitaan orang lain. Dalam kaba Amggun Nan Tungga, tokoh Niniak Rang Paladang peduli terhadap lingkungannya. Hal itu dapat dilihat pada kutipan berikut.

Di Gondoriah sayang, kembalilah engkau pulang kulit yang halus andaikan tergores, rambut yang panjang andaikan kusut, kalau sampai sayang disana, yaitu dikaki gunung Ledang, tunggang bagaikan pinang sebatang, kemana Gondo akan lalu, hanya berpijak diatas batu, ada bergantung di akar lapuk, duri akan mencucuk betis, hilalang akan menikam dada, pimping akan menggores wajah, rotan andaikan pintas memintasi, yaitu di puncak gunung Ledang. (Anggun Nan Tungga, 1982:104)

Kemunculannya hanya sebentar, tetapi Niniak Rang Paladang berhasil memberi kesan yang menarik karena kepeduliannya yang besar terhadap keselamatan dan kebahagiaan Gondan Gondoriah. Sayang sekali, dia juga sama dengan Niniak kabayan, tidak punya kemampuan untuk mecegah dan akhirnya pasrah. 


\section{Simpulan}

Berdasarkan hasil pembahasan tadi, dapat ditarik simpulan sebagai berikut. Citra tokoh perempuan yang digambarkan dalam kaba Anggun Nan Tungga menunjukkan bahwa pada umumnya tokoh perempuan mempunyai kepribadian sangat baik. Mereka memiliki kedua aspek citra perempuan, yaitu citra perempuan sebagai pribadi dan citra perempuan sebagai anggota masyarakat. Citra perempuan sebagai pribadi terbagi atas empat macam, yaitu: citra perempuan penyayang, citra perempuan penyabar, citra perempuan lemah lembut dan citra perempuan yang memiliki orientasi hidup. Sementara itu, citra perempuan sebagai anggota masyarakat terbagi atas dua bagian yaitu citra perempuan dalam hubungan dengan keluarga dan lingkungan sekitar. Hal itu sudah mencerminkan tokoh perempuan yang diidealkan. Perempuan merupakan tiang kokoh dalam rumah tangga dan masyarakat. Mereka berfungsi memberikan arahan dan pengaruh besar bagi generasi muda. Citra Perempuan dalam kaba berhubungan erat dengan kepribadian individual anggota masyarakat menurut sistem sosial masyarakat Minangkabau. Bahkan, perempuan dalam kaba merupakan pengukuhan kepribadian anggota masyarakat Minangkabau.

Dari simpulan tadi peneliti menyarankan bahwa karya sastra sebagai karya kreatif hendaknya pemahaman terhadap karya sastra dilakukan secara kreatif pula. Hal itu berlaku pula terhadap karya sastra daerah Minangkabau, sebagai karya kreatif yang khas Minangkabau dia merefleksikan dan merefraksikan realitas objektif. Oleh sebab itu, penelitian dan analisis terhadap karya sastra Minangkabau, terutama kaba Minangkabau masih perlu ditingkatkan karena dia dapat dijadikan sebagai bahan perbandingan bagi kehidupan. 


\section{DAFTAR PUSTAKA}

Asri, Jasnur, 1996. Orientasi Nilai Budaya Tokoh Wanita dalam Novel Indonesia. Jakarta: Pusat Pembinaan dan Pengembangan Bahasa.

Armini, 1986. Citra Wanita Pekerja dalam Empat Novel. Tesis Universitas Gadjah Mada Yogyakarta.

Barnhouse, Ruth T., (Terj. Lunandi). 1998. Identitas Wanita. Yogyakarta: Kanisius.

Budiman, Arief, 1999. Pembagian Kerja Secara Seksual. Jakarta: Gramedia.

Bakar, Jamil.1989. Kaba Minangkabau. Jakarta: Depdikbud.

Baried, Baroroh, 1996. Citra Wanita dalam Kebudayaan Indonesia. Makalah Seminar Nasional Wanita Indonesia: Fakta dan Citra, Jakarta 23 - 25 Agustus.

Chamamah-Soeratno, Siti, 1994. Sastra dalam Wawasan Pragmatik Tinjauan alas Asas Relevansi di dalam Pembangunan Bangsa. Pidato Pengukuhan Jabatan Guru Besar pada Fakultas Sastra Universitas Gadjah Mada Yogyakarta, tanggal 24 Januari.

Damono, Sapardi Djoko, 1979. Sosiologi Sastra: Sebuah Pengantar Ringkas. Jakarta: Pusat Pembinaan dan Pengembangan Bahasa.

Djamaris, Edwar. 2002. Pengantar Sastra Rakyat Minangkabau: Jakarta Yayasan Obor Indonesia. Jassin, H.B., 1983. Sastra Indonesia sebagai Wargo Sastra Dunia. Jakarta. Gramedia.

Kartono Kartini. 2007. Psikologi Wanita. Bandung: Mandar Maju.

Ridjal, Fauzi, 1993. Dinamika Gerakan Perempuan di Indonesia. Yogyakarta: Tiara Wacana Yogya.

Junus, Umar, 1994a. Kaba dan Sistem Sosial Minangkabau: Suatu Problem Sosiologi Sastra. Jakarta: Gramedia.

Navis. A.A. 1986. Alam Takambang jadi Guru. Jakarta: PT Grafiti Pers.

Nurgiyantoro, Burhan. 1995. Teori Pengkajian Fiksi. Yogyakarta: Gajah Mada University Press.

Moleong, Lexi J. 2005. Metode Penelitian Kualitatif. Bandung: Remaja Rosda Karya.

Mahkota, Ambas. 1982. Kaba Anggun Nan Tungga. Bukittinggi: Balai Buku Indonesia.

Muhardi dan Hasanuddin W.S. 1992. Prosedur Analisis Fiksi. Padang : IKIP Padang Press.

Muhardi. 2000. Homo Humanus. Padang: Universitas Negeri Padang.

Purwanto, Ngalim. 2001. Psikologi Pendidikan. Bandung: Remaja Karya.

Udin, Syamsuddin, 2006. Kaba Minangkabau Karya Syamsuddin Sutan Rajo Endah: Tinjauan dari Sudut Sosial Budaya. Padang: Penelitian untuk Pusat Pembinaan dan Pengembangan Bahasa. Jakarta.

Semi, M. Atar. 1993. Metode Penelitan Sastra. Bandung: Angkasa Bandung.

Sugono, Dendy. 2008. Kamus Besar Bahasa Indonesia. Jakarta: PT Gramedia Pustaka Utama.

Teeuw, A. 1994. Sastra dan Ilmu Sastra. Jakarta: Gramedia

W.S., Hasanuddin. 1997. Profil Wanita dalam Novel-Novel Indonesia Sebelum Perang. Padang : Universitas Negeri Padang. 